DOI: 10.46340/eppd.2021.8.1.15

\author{
Olena Chaltseva, ScD in Political Science \\ ORCID ID: https://orcid.org/0000-0003-3922-7619 \\ Vasyl' Stus Donetsk National University, Vinnytsia, Ukraine
}

\title{
A SYSTEMATIC APPROACH TO PUBLIC POLICY RESEARCH
}

\author{
Олена Чальцева, д. політ. н. \\ Донецкий национальний університет імені Василя Стуса, Вінниця, Україна
}

\section{СИСТЕМНИЙ ПІДХІД У ДОСЛІДЖЕННІ ПУБЛІЧНОї ПОЛІТИКИ}

The theory of political systems allows us to consider public policy as a response of the system to the demands that come from the external environment. The use of system-structural, systemfunctional and system-dynamic types of analysis within the systematic approach will bring us closer to understanding how the public space is arranged, what functional capabilities of public institutions will determine the system dynamics and effectiveness of systemic changes in the process of interaction of policy actors.

The systematic approach allows us to review public policy as an integral system that is dynamically self-developing, striving for referentiality and efficiency, where each element, while interacting, functionally ensures its existence.

The functional aspect of the system analysis of public policy is related to the study of stable, organizationally and institutionally formed types of activity of the subjects. Optimal functioning of the system ensures the maximization of its functions, which are performed by multiple actors.

Based on the works of N. Luman, A. Giddens, Y. Reznik, A. Galkin and others, the main power of the holistic system lies in the ability to synthesize and construct its elements, reformat its structure in response to the internal and external influences of the environment. It has been established that public policy, as a system that self-organizes, is able to create and maintain both internal equilibrium, i.e. social stability, and external one (equilibrium with the environment). At the same time, it is a dynamic system, which determines the direction and limits of its own development by means of subject-object interactions.

The level of development of coordination links determines the path of public policy "from bottom to top". If the community is institutionally ready to take part in the decision-making process, consequently, the coordination links will have an intensive character and, therefore, the effect of the public "from bottom to top" will be productive.

Keywords: system, systematic approach, analysis, equilibrium, interaction, function.

Публічна політика представлена в політичній науці як полікомпонентна й багаторівнева категорія, тому в науковій літературі не існує одновимірного та універсального пояснення іï сутнісної характеристики. Починаючи з 50-х рр. ХX ст., дослідники знаходяться в методологічному пошуку, вибираючи все нові й нові теми для аналізу публічної політики, включаючи інноваційні методи дослідження, формуючи нові теорії відповідно до сучасних парадигмальних тенденцій у науці й подій, які є одним із головних каталізаторів наукових змін. Величезне значення для дослідницької стратегії при вивченні публічної політики має системний підхід, який надає можливість комплексно підійти до проблеми.

Системний підхід, завдяки якому публічна політика представлена як цілісна система, що динамічно саморозвивається, прагне до референтності й ефективності, де кожен елемент, взаємодіючи, функціонально забезпечує ії існування. На підставі робіт Д.Істона, Г.Алмонда, Н.Лумана, Е.Гідденса, Ю.М.Резніка, А.Н.Галкіна та ін. з'ясовано, що головна властивість цілісної системи полягає в здатності синтезувати, конструювати свої елементи, переформатувати свою структуру у відповідь на внутрішні й 
зовнішні впливи середовища. Публічна політика, як система, що самоорганізується, здатна створювати й підтримувати як внутрішню рівновагу, тобто соціальний порядок, так і зовнішню (рівновагу 3 навколишнім середовищем). У той же час, вона є динамічною системою, яка за допомогою суб'єктоб’єктних взаємодій визначає спрямованість і межі власного розвитку.

Системне визначення публічної політики призвело до необхідності використання в дослідженні системно-структурного, системно-функціонального та системно-динамічного видів аналізу.

Системно-структурний аналіз акцентує нашу увагу на структурній складовій публічної політики як системи, що включає в себе процес взаємодії акторів в рамках єдиного простору. Він фокусує увагу на структурних змінах, що ведуть до узгодженої взаємодії суб'єктів, утворення структур та проблеми розподілу ресурсів в умовах зовнішньої невизначеності ${ }^{1}$.

Конкретний зміст і типи суспільних відносин визначаються факторами об'єктивного й суб'єктивного порядку. До об'єктивних чинників щодо публічної політики ми можемо віднести: характер режимного середовища, економічні фактори, рівень розвитку інституцій, тип політичної культури. Суб'єктивні чинники пов'язані з індивідуальними уявленнями, ідентичністю, культурноціннісним змістом, потребами та інтересами людей.

У системному підході для характеристики стійких аспектів структури систем використовується поняття «інститути». Так, автор теорії структурації Е. Гідденс вважає, що вони є найбільш стабільними рисами соціальних систем, покликаними упорядковувати й регулювати соціальні практики ${ }^{2}$.

Включення в системну теорію інституціональної складової дозволяє представити публічну політику як особливу цілісну інституціональну систему, що складається із сукупності інститутів, які знаходяться між собою у взаємозв'язках.

У різних типах систем характер інституціоналізованих практик форматується в залежності від наступних показників: тип зв'язків і відносин між акторами системи (превалювання горизонтальних або вертикальних зв’язків); спосіб регуляції соціокультурної системи (переважно нормативноправова, морально-психологічна, «змішана» (ціннісно-нормативна, морально-правова)); ступінь формалізації зв'язків усередині системи (жорстко-ієрархізований, неієрархізований вид зв'язків); характер виникнення й розвитку системи (природний, інстальований, імітаційний тощо); ступінь відкритості системи (відкрита, закрита, напівзакрита); тип членства в системі (приписаний, інсталяційний, природно-обумовлений, добровільний тощо); рівень виконуваних функцій ${ }^{3}$.

Публічні інститути, що розглядаються крізь призму системного підходу, умовно діляться на громадського й негромадянського типу (за Н. Луманом, що належать до життєвого й системного світів) $^{4}$, які характеризуються горизонтальними (громадські інститути) й вертикальними (державні інститути) практиками взаємодії.

Громадські інститути - це історично певний різновид соціокультурних систем, які характеризуються в цілому горизонтальними й неформальними зв'язками, добровільним типом членства, відкритістю, що встановлює й підтримує організаційні, ціннісно-нормативні та інші межі автономної діяльності й конвенційної взаємодії людей, а також спрямовує їх активність у бік більш ефективної та всебічної актуалізації діяльності відповідно до критеріїв громадянськості (цілісність, свобода і самодіяльність).

Такий тип інститутів забезпечує горизонтальну взаємодію акторів (зв'язок координації) при домінуючій ролі громадянського суспільства в публічній політиці. Рівень розвитку координаційних зв'язків визначає траєкторію публічної політики «знизу - вгору». Якщо громадянське суспільство інституціонально готове брати участь у процесі прийняття рішень, відповідно, зв'язки координації матимуть інтенсивний характер, а значить, і вплив «публіки» «знизу - вгору» буде продуктивним.

Вертикальні практики суспільно-політичної взаємодії політичних акторів являються традиційним типом відносин, де ключовими суб'єктами є держава та інші інституції, що забезпечують ієрархічний зв' язок між учасниками суспільного процесу за траєкторією «згори - вниз» (зв’язок субординаціі).

\footnotetext{
${ }^{1}$ Резник Ю. М. (2003). Введение в соичильную теорию: социальная системологии. Москва: Наука.

${ }^{2}$ Гидденс, Э. (2005). Устроение общества: Очерк теории структурации. Москва: Академический Проект.

${ }^{3}$ Резник, Ю. М. (2003). Введение в социильную теорию: соичиальная системология. Москва: Наука, 281.

4 Луман, Н. Л. (2004). Общество как социальная система. Москва: Логос.

${ }^{5}$ Бергер, П., Лукман, Т. (1995). Социальное конструирование реальности. Трактат по сочиологии знания. Москва: Наука.
} 
Обидва види практик взаємодії (взаємозв'язку) відзначаються зворотним зв'язком, який забезпечує розвиток системи, ії зміну, відтворення й реакцію на передачу імпульсів як згори - вниз, так і знизу - вгору. Основні принципи функціонування зворотного зв'язку в громадських системах носять універсальний характер. Так, в усіх випадках стійкий дефіцит такого зв'язку загрожує кризою, а в кінцевому рахунку навіть розпадом системи ${ }^{1}$.

У відносинах між громадянським суспільством і державою зворотний зв'язок $\epsilon$ показником розвитку системи. Вертикальна структуризація суспільства зазвичай призводить до того, що канали зворотного зв'язку працюють не на повну потужність (або взагалі перестають працювати). Політична система, замикаючись на собі, перестає відстоювати загальний інтерес, громадянське суспільство набуває корпоративних рис, перестає впливати на суспільно-політичний процес, у суспільстві спостерігається відчуження ${ }^{2}$.

Співвідношення вертикальних і горизонтальних практик взаємодії публічних акторів, що виявляється або в зв'язках кооперації, або в конфліктних зв'язках, є показником функціонування системи та їі динамічної рівноваги.

Функціональний аспект системного аналізу публічної політики пов'язаний із вивченням стійких, організаційно й інституціонально оформлених видів діяльності суб'єктів. Оптимальне функціонування системи забезпечує досягнення максимізації iï функцій, які виконуються множинними акторами.

Системно-функціональний аналіз спрямований на вивчення функціональної складової публічної політики, яка може бути представлена як система інститутів та інших інституціональних утворень, що встановлюють і підтримують стійкі форми діяльності акторів. Системнофункціональний аналіз також орієнтований на вивчення причин і факторів оптимізації (гармонізації або дисгармонізації) відносин між різнорівневими суб'єктами політики, на виявлення кооперативної готовності й конвенціональних можливостей суб'єктів, що реалізуються в процесі їх спільної діяльності з виробництва, розподілу та використання ресурсів.

Публічні інститути забезпечують реалізацію таких функцій усистемі, як соціальнопродуктивна, управлінська, дистрибутивна, соціалізуюча, комунікативна, інформаційна, медіативна, нормативно-правова тощо. Настільки різнобічна участь (за видами функцій) у публічному процесі має відповідати такій умові, як функціональна сумісність акторів публічної політики, яка виражається в загальній взаємозалежності їх дій з точки зору ефективного та оптимального функціонування цілого системного організму.

Основна функція публічної політики як системи - це інтеграційна, яка орієнтована на солідаризацію й соціальну злагоду інституціоналізованих і неінституціоналізованих акторів, що досягається в процесі дискурсивних практик і конвенційної взаємодії. Публічні інститути несуть на собі основне навантаження у справі інтеграції суспільства. Вони володіють більшою організаційною можливістю системно брати участь у виробництві й реалізації політичних рішень.

Функціональний аналіз публічної політики досить широко й різнопланово представлений в роботах дослідників, які пов'язують його з процесом прийняття рішень і політико-управлінськими процесами. Управлінський вимір публічної політики дозволяє визначити інституціональні та технологічні можливості акторів політичного процесу у виробництві публічних рішень. У системі публічного управління існують політична й адміністративна підсистеми, що задають інституціональний коридор для участі громадянського суспільства в процесі формування порядку денного, прийняття рішень i контролю за їх виконанням. Політична підсистема публічного управління результує дискурсивність публічної сфери за допомогою системи політичного представництва й практик взаємодії, формуючи стратегію розвитку системи.

Змістове наповнення будь-якої національної моделі публічної політики залежить від наступних системних характеристик: 1) політичного режиму держави, що розглядається, який визначає інституціональний каркас розвитку системи; 2) рівня стабільності системи, тобто наскільки досліджувана система стабільна або знаходиться в стані трансформації, остання обставина має особливе значення для аналізу публічної політики держав, які знаходяться в процесі переходу до нової моделі свого політичного розвитку; 3) ступеня розвиненості публічних інститутів, їх

\footnotetext{
${ }^{1}$ Галкин, А. А. (2012). Обратная связь и публичная сфера. Публичная политика в контексте задач модернизации России: конструктивный потенциал и формы использования. Москва: Российская ассоциация политической науки, 39-53.

2 Там само.
} 
законодавче оформлення і практична діяльність в політичному просторі; 4) системи публічного управління, в якій формується курс розвитку системи і існує інституціоналізований комплекс каналів взаємодії між акторами політичного процесу, що впливають на прийняття політичних рішень. Від заданих характеристик буде залежати те, наскільки публічна політика відповідає сучасним глобальним трендам і практиці адміністрування та управління з якісно новим рівнем громадянської участі в здійсненні функцій співуправління державою.

Кожна політична система має свій набір національних складових владних відносин, інститутів, особливостей формування стратегії розвитку і політико-ідеологічних цінностей. Проте, загальною обставиною для всіх держав є зв'язок між режимом політичної системи і характером публічної політики. Політична система з притаманним їй режимом визначає характер і направленість публічної політики, а остання змушує проводити модифікацію структурних компонентів системи.

Публічна система, будучи «живим організмом» і постійно саморозвиваючись, знаходиться в стані динамічного розвитку (динамічного процесу) всіх своїх структурних елементів. Динамічні процеси - це процеси взаємоузгодженого й взаємопов' язаного розвитку суб' єктів, за яким недостатні здатності одних суб'єктів компенсуються за рахунок переваг (ресурсів) інших. В умовах контрольованого суперництва програм діяльності суб'єктів більше можливостей для самореалізації отримує той суб'єкт, програма якого виявляється більш ефективною з точки зору оптимального використання ресурсів ${ }^{1}$.

Системно-динамічний аналіз динамічних процесів публічної політики орієнтований на:

- вивчення причин, чинників та механізмів публічної політики, що розглядається в єдності ії структурних і функціональних змін;

- огляд і визначення логіки змін кількісних і якісних характеристик в межах певного публічного простору та протягом певного часу; політики;

- поетапне вивчення різних типів системної динаміки процесуальних характеристик публічної

- виявлення чинників, тенденцій і результатів діяльності суб'єктів, які в умовах конфлікту та конкуренції прагнуть до власного коеволюційного й синхронного саморозвитку.

Взаємодіючи між собою в динамічному просторі, актори публічної політики в певний момент можуть досягати точки біфуркації у виборі варіантів рішень. Головним джерелом їх розвитку $€$ соціальні інновації, тобто організовані дії людей, спрямовані на оновлення їх якісного змісту й структурного розмаїття. Ще одним джерелом служать комунікаційне середовище та дискурсні практики, які формують інформаційне поле, визначають ціннісно-ідеологічний зміст публічної сфери, створюють публічні майданчики для обговорення питань, що цікавлять і впливають на прийняття рішень.

Публічна політика - це не постійна величина, вона може видозмінюватися і набувати згодом нової мережевої комбінації учасників політичного процесу. Динаміка і характер таких змін залежать від багатьох чинників: від рівня організованості, часу взаємодії, інтенсивності та якості комунікації акторів, стабільності системи, режимності, соціокультурних показників тощо. Змінні публічної політики ще недостатньо теоретично осмислені, тому вчені часто звертаються до вже існуючих теорій у спробі пояснити вищевказані феномени. Наприклад, однією з таких теорій $є$ концепція лимінальності систем (від латинського limen - поріг), розроблена такими вченими, як: А. ван Геннеп, В. Тернер, Н. Біч, Б. Румелію, Л. В. Сморгунов та ін.

Дослідник Л. В. Сморгунов вважає, що лимінальна система- це прикордонні (між) або витіснення на периферію (маргінальні) зони людського існування, які не можуть характеризуватися певними соціально-територіальними, соціальними, культурними, політичними, гендерними, національними та ін. особливостями, а являють собою невизначеності і змішування рис. Лимінальні системи різноманітні: ними можуть характеризуватися розташовані «між» держави, території прикордоння, анклави, витіснені соціальні простори (концтабори, гетто, лимінальні культури та ін.) ${ }^{2}$. До лимінальних систем ми можемо віднести й Інтернет як віртуальний комунікативний простір, який постійно «рухомий» і «прикордонний». Лимінальна публічна політика важко піддається емпіричному аналізу і вимагає дуже точної операціоналізації розглянутих об'єктів. Порівняння і моделювання

\footnotetext{
${ }^{1}$ Резник Ю.М. (2003). Введение в соииальную теорию: сочиальная системология. Москва: Наука.

${ }^{2}$ Сморгунов, Л. В. (2012). Политическое «между»: феномен лиминальности в современной политике. Полис, 5 , 262.
} 
таких систем дадуть можливість знаходити шляхи подолання прикордонних і конфліктних станів там, де цей процес може регулюватися політичними інститутами.

Динаміка інституціональних змін у полі публічної політики визначається конструктивними й творчими діями автономних акторів, які прагнуть досягнення та реалізації власних інтересів. Нові інституціональні структури, що виникають у результаті впливу зовнішніх факторів і складання нових громадських відносин у різних типах систем, формують нові системи зв'язків і формат відносин відповідно до нових викликів ззовні й зсередини.

Розглянувши можливості використання трьох видів системного підходу вивченні публічної політики, можна зробити висновок, що вони допомагають розкрити концептуальний зміст публічної політики як складної системи що динамічно саморозвивається, прагне до референтності й ефективності, де кожен елемент, взаємодіючи, функціонально забезпечує іiї існування.

У межах теорії політичних систем можна розглянути публічну політику як відповідь системи на запити, що надходять із зовнішнього середовища. Застосування системно-структурного, системнофункціонального та системно-динамічного видів аналізу в межах системного підходу наблизить нас до розуміння того, як влаштований публічний простір, які функціональні можливості публічних інститутів визначатимуть системну динаміку й ефективність системних змін у процесі взаємодії акторів політики.

\section{References:}

1. Reznik, Yu. M. (2003). Vvedenie v socialnuyu teoriyu: socialnaya sistemologii [Introduction to Social Theory: Social Systemology]. Moscow: Nauka. [in Russian].

2. Giddens, E. (2005). Ustroenie obshestva: Ocherk teorii strukturacii [The structure of society: An essay on the theory of structuring]. Moscow: Akademicheskij Proekt. [in Russian].

3. Luman, N. L. (2004). Obshestvo kak socialnaya sistema [Society as a social system]. Moscow: Logos. [in Russian].

4. Berger, P., Lukman, T.(1995). Socialnoe konstruirovanie realnosti. Traktat po sociologii znaniya [Social construction of reality. A treatise on the sociology of knowledge]. Moscow: Nauka. [in Russian].

5. Galkin, A. A. (2012). Obratnaya svyaz i publichnaya sfera [Feedback and the public sphere]. Publichnaya politika $v$ kontekste zadach modernizacii Rossii: konstruktivnyj potencial i formy ispolzovaniya [Public policy in the context of the tasks of modernizing Russia: constructive potential and forms of use]. Moscow: Rossijskaya associaciya politicheskaya nauka, 39-53. [in Russian].

6. Smorgunov, L. V. (2012). Politicheskoye «mezhdu»: fenomen liminalnosti v sovremennoy politike [Political "between": the phenomenon of liminality in modern politics]. Polis, 5, 260-265. [in Russian]. 